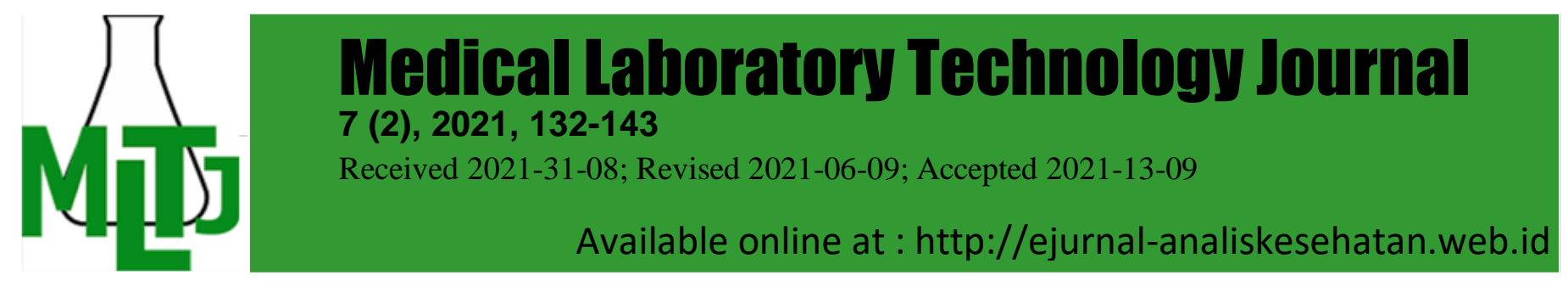

\title{
Cowpea (Vigna unguiculata) Extract Reduce Malondialdehyde Levels and Prevent Aortic Endothelial Cell Decline in Ovariectomized Rats
}

\author{
Ni Putu Sri Haryati ${ }^{1}$, *Elisa Danik Kurniawati ${ }^{2}$, Tanti Tri Lestary ${ }^{3}$, Eviana \\ Norahmawati $^{4}$, I Wayan Arsana Wiyasa ${ }^{5}$, Dwi Yuni Hidayati ${ }^{6}$, Tatit Nurseta $^{7}$
}

${ }^{1}$ Master of Midwifery, Faculty of Medicine, University of Brawijaya, Malang, Indonesia and Bachelor of Midwifery, Faculty of Health, Institute of Technology and Health Bali,

${ }^{2}$ Master of Midwifery, Faculty of Medicine, University of Brawijaya, Indonesia,

${ }^{3}$ Master of Midwifery, Faculty of Medicine, University of Brawijaya, Malang, Indonesia and Department of Midwifery, Faculty of Health, University of Borneo Tarakan,

${ }^{4}$ Department of Anatomical Pathology, Faculty of Medicine, University of Brawijaya, Indonesia, ${ }^{5}$ Division of Fertility, Endocrinology and Reproduction, Obstetric and

Ginecology Laboratory, Saiful Anwar General Hospital, Faculty of Medicine, University of Brawijaya, Indonesia, ${ }^{6}$ Department of Microbiology Laboratory, Faculty of Medicine, University of Brawijaya, Indonesia, Dr. Saiful Anwar General Hospital, Indonesia, ${ }^{7}$ Department of Obstetrics and Gynecology, Faculty of Medicine, University of Brawijaya, Dr. Saiful Anwar General Hospital, Malang, Indonesia. *Email : elisadk11@gmail.com. DOI: 10.31964/mltj.v0i0.402

Abstract: Estrogen has anti-oxidative and anti-inflammatory properties, but its levels decrease in postmenopausal women who can trigger oxidative stress. One of the most damaging effects of ROS is lipid peroxidation, and the end product is Malondialdehyde (MDA). Similarly, aging endothelium has increased oxidative stress and endothelial cell sensitivity to apoptosis. This study aimed to determine the effect of cowpea extract on serum MDA levels, aortic endothelial cell counts, and brain MDA levels in the ovariectomy model. Cowpea extract can be used as an alternative to prevent and overcome the effects that occur during menopause, such as cardiovascular problems, decreased bone mineral density, and dementia. The study used 15-month-old female Rattus norvegicus, divided into six groups (OVX, SHAM, OVX+estradiol, OVX+Vu 1.25; 2.5; and $5 \mathrm{mg} / \mathrm{kg}$ BW/day). Serum and brain MDA levels were examined by ELISA method, while the number of aortic endothelial cells were examined on histopathological preparations with Hematoxylin \& Eosin (HE) staining. The mean value of serum and brain MDA levels decreased with an increase in the dose given ( $p-$ value 0.016). The mean value of aortic endothelial cells between the dose groups did not significantly differ. However, the mean value showed an increasing trend as the dose of cowpea extract was given. The results of this study indicate that the extract of cowpea has the potential as an antioxidant to reduce serum and brain MDA levels, prevent a decrease in the number of aortic endothelial cells. As prevention, cowpea extract can be used as an antioxidant and consumed since premenopause to minimize problems that occur during postmenopause.

Keywords: Vigna unguiculata; ovariectomy; menopause

\section{INTRODUCTION}

Menopause is a condition of permanent cessation of menstruation for at least 12 months in women, which occurs at a median age of 51 years (Peacock \& Ketvertis, 2020). The state of menopause can be a problem in public health services caused by Corresponding Author: Elisa Danik Kurniawati

Master of Midwifery, Faculty of Medicine, University of Brawijaya, Jl. Veteran, Ketawanggede,

Kec. Lowokwaru, Malang, East Java, Indonesia. 65145

Email: elisadk11@gmail.com 
hormonal changes such as a decrease in the endogenous estrogen hormone. Estrogen has anti-oxidative and anti-inflammatory properties, but its levels decrease in postmenopausal women (Serviente et al., 2016; Ventura-Clapier et al., 2017).

It reduced estrogen hormone during menopause results in disruption of the production of natural antioxidant enzymes in the body such as glutathione peroxidase, which results in increased Reactive Oxygen Species (ROS) in the brain and triggers Oxidative Stress (OS) (Montoya-estrada et al., 2020). OS in the Central Nervous System (CNS) can seriously damage the brain through increased intracellular free $\mathrm{Ca2+}$, the release of excitatory amino acids, and neurotoxicity (Huang et al., 2016). In addition, an increase in ROS can also reduce the antioxidant defense system in bones (Muthusami et al., 2005). One of the most damaging effects of ROS is lipid peroxidation, and the end product is Malondialdehyde (MDA) (Phaniendra et al., 2015). A high concentration of MDA proves the low antioxidant status so that it cannot prevent the reactivity of free radical compounds and enter the blood vessels (Hardiany et al., 2020). Lipid peroxide can also convert ROS into reactive compounds capable of crosslinking Deoxyribonucleic Acid (DNA) proteins and induce cell apoptosis. If apoptosis occurs in neuronal cells, it will cause dementia, but if apoptosis occurs in osteoblast cells, it will cause a decrease in bone density (Gaschler \& Stockwell, 2017; Qin et al., 2019).

In the cardiovascular system, the hormone estrogen plays an essential role because it protects the endothelium and smooth muscle of blood vessels, thus underpinning this protection in premenopausal women (El Khoudary et al., 2015; Kassi et al., 2015; Klawitter et al., 2017; Usselman et al., 2016). Endothelial cells play an essential role in monitoring every cardiovascular function with their sensory abilities (Mccarron et al., 2017; Vanhoutte et al., 2017). It is known that endothelial cells in the aorta exhibit anticoagulant, antiadhesive, and anti-inflammatory properties (Jie-mei Wang et al., 2016). However, the aged endothelium may undergo functional changes such as decreased vasomotor function and decreased angiogenic ability. This may be due to increased oxidative stress, decreased endothelial cell replacement, and increased sensitivity of endothelial cells to apoptosis (Ross, 2018; Jinsong Wang et al., 2011). Endothelial cell loss or dysfunction can cause vascular damage so that both endogenous and extrinsic coagulation pathways are activated, and vascular stenosis or occlusion occurs (Meng et al., 2018).

Genistein, a natural flavonoid found in Leguminosae plants, is a phytoestrogen with estrogenic activity both as agonists and antagonists (Sureda et al., 2017). Previous studies have shown that genistein contained in cowpeas acts as an antioxidant to reduce oxidative stress (Devi et al., 2017; Kusumaningrum et al., 2017; Sureda et al., 2017). Braxas (2019) showed that genistein supplementation for 12 weeks reduced MDA by $11.48 \%$ compared to the placebo group (Braxas et al., 2019). The large number of women who cannot undergo Estrogen Replacement Therapy (ERT) and the increased risk of stroke or venous thromboembolism allow the choice of phytoestrogens or genistein to be a safer preventive measure. This safe and effective therapeutic approach can be used to improve the quality of life in postmenopausal women. The intervention is not only in the form of hormonal therapy but also non-hormonal with herbal therapies such as cowpea (Schneider \& Birkhäuser, 2017).

Previously, research on the effects of genistein and cowpeas had been carried out. However, there had never been a study using cowpea with the KT4 variety, which this variety has a higher genistein content than other varieties (Azizah et al., 2014; Braxas et al., 2019). In addition, this is the first research using a 15-month-old rat study 
sample so that the aging condition is more representative. This study aimed to determine the effect of cowpea extract on serum MDA levels, aortic endothelial cell counts, and brain MDA levels in the Rattus norvegicus ovariectomy model.

\section{MATERIALS AND METHODS Experimental Animal}

The research was conducted in several laboratories within the Faculty of Medicine, Universitas Brawijaya, Malang, Indonesia using female Rattus norvegicus experimental animals aged 15 months old and weighing about 200-350 grams. This research has been approved by the Animal Care and Use Committee Research Universitas Brawijaya Malang with registration number 106-KEP-UB-2020. Acclimatization is carried out for seven days and randomization into six sample groups. Group 1 is a negative control, namely the experimental group of sham models given $1 \mathrm{ml}$ of aquadest/day. Group 2 is a positive control, namely a group of experimental animals made postmenopausal by ovariectomy and given $1 \mathrm{ml}$ of aquadest/day. Groups 3-6 are experimental groups of ovariectomized rat with treatment, namely in group 3 were given $17-\beta$ estradiol $0.18 \mathrm{mg} / \mathrm{kg}$ BW/day, group 4 were given ethanolic extract of Vigna unguiculata $1.25 \mathrm{mg} / \mathrm{kg} \mathrm{BW} /$ day, group 5 were given ethanolic extract of Vigna unguiculata $2.5 \mathrm{mg} / \mathrm{kg} \mathrm{BW} /$ day, and group 6 were given an ethanolic extract of Vigna unguiculata $5 \mathrm{mg} / \mathrm{kg} \mathrm{BW} /$ day. Ovariectomy and sham procedures were carried out on day 8 , followed by stabilization for 28 days. All experimental animals were given aquadest or standard drugs or extracts according to groupings for 40 days.

\section{Ethanolic extract of Vigna unguiculata}

Simplisia Vigna unguiculata with KT4 variety was obtained from Balai Penelitian Tanaman Aneka Kacang dan Umbi (Balitkabi) Malang, which was extracted with 96\% ethanol solvent at the Pharmacology Laboratory of the Faculty of Medicine. The extract was administered for 40 days (starting on day 29 from ovariectomy) at a dose of $1.25 ; 2.5$; and $5 \mathrm{mg} / \mathrm{kg} \mathrm{BW} /$ day.

\section{Serum MDA Levels}

The rat serum was taken at the time of surgery and allowed to clot for 2 hours at room temperature, then immediately centrifuged for 15 minutes at $1000 \times \mathrm{g}$ at a temperature of $2-8^{\circ} \mathrm{C}$. Serum MDA levels were measured using the Elabscience MDA ELISA Kit Catalog No. E-EL-0060 with ELISA Sandwich principle

\section{Aortic Endothelial Cells}

Counting the number of aortic endothelial cells were obtained by transverse aortic cutting, and histopathological preparations were made with Hematoxylin \& Eosin (HE) staining and read with 400x magnification in 10 fields of view.

\section{Brain MDA Levels}

Rat brains that have been stored in the freezer are placed at room temperature. The brains were cut and weighed with a weight of 0.1-0.5 grams, then placed in a cup and given aquadest in a ratio of 1:10. To make the supernatant, the brains were crushed until the brain solids were crushed and then placed in a centrifuge tube and centrifuged for 10 minutes at $800 \times \mathrm{xg}$ at a temperature of $2-8^{\circ} \mathrm{C}$. The ELISA method used the Elabscience MDA ELISA Kit Catalog No to calculate MDA levels from brain supernatant samples. E-EL-0060 with ELISA Sandwich principle

\section{Statistic analysis}

Data are presented as mean \pm standard deviation. Previously, the data were analyzed by normality test, and all data were categorized as normally distributed. Furthermore, One Way ANOVA is used to prove the research hypothesis. The results of the One Way Anova test concluded that there was a significant difference ( $p$-value 
$<0.05)$, then the analysis continued with the multiple comparison test, namely Least Significant Difference (LSD), to determine the significant difference between the treatment groups.

\section{RESULTS AND DISCUSSION \\ Serum MDA Level}

Figure 1 shows the mean of Serum MDA levels in each group. The mean value of serum MDA levels seemed to decrease with increasing the dose given. The One Way ANOVA test results on the serum MDA levels of ovariectomized rats showed a significant difference ( $p$-value 0.016). Then the analysis was continued with the Least Significant Difference (LSD). It was found that there was a significant difference ( $p$ value 0.004) in the mean serum MDA level between the extract dose group of 1.25 $\mathrm{mg} / \mathrm{kg} \mathrm{BW}$ and the extract dose group of $5 \mathrm{mg} / \mathrm{kg}$ BW. So in this study, the dose of cowpea extract (Vigna Unguiculata) $5 \mathrm{mg} / \mathrm{kg} \mathrm{BW}$ was the optimum dose to reduce serum MDA levels in ovariectomized rats.

Meanwhile, the comparison between the group given the dose of Vigna unguiculata extract and the group given $17 \beta$-estradiol was not statistically significant. The average administration of 17-estradiol was lower than Vigna unguiculata extract at a dose of $1.25 \mathrm{mg} / \mathrm{kg}$ BW and $2.5 \mathrm{mg} / \mathrm{kg}$ BW. However, higher than the administration of Vigna unguiculata extract at a dose of $5 \mathrm{mg} / \mathrm{kg} \mathrm{BW}$.

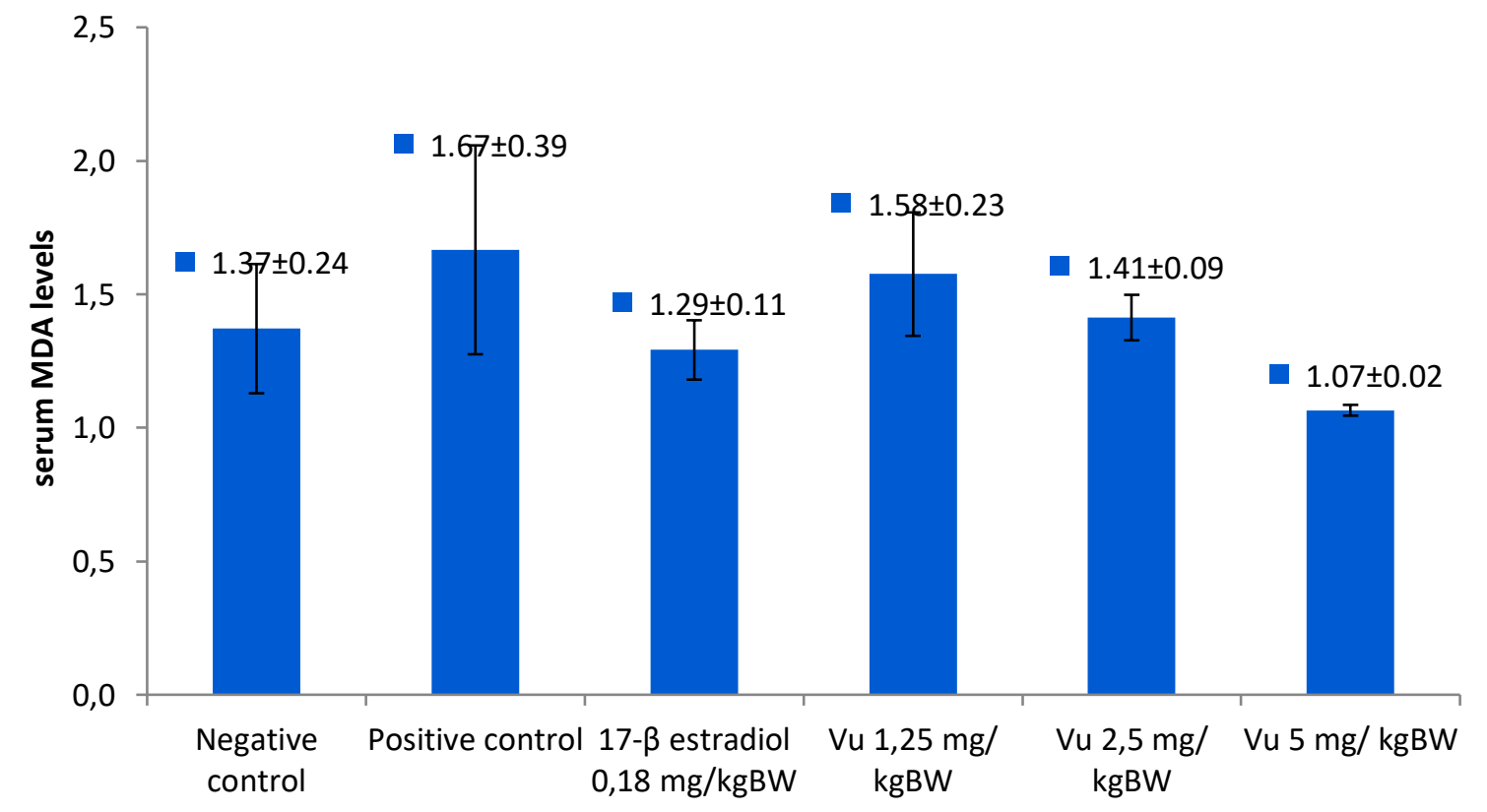

Description: The mean levels of MDA ( $\mathrm{mg} / \mathrm{mL})$ serum were measured using ELISA

Figure 1. Histogram of the Effect of Cowpea (Vigna unguiculata) Ethanol Extract on Serum MDA Levels in Rattus norvegicus Ovariectomy Model

\section{Aortic endothelial cell count}

Figure 2 shows the mean aortic endothelial cell count in all groups. The results of the One way ANOVA test proved that there was a significant difference in the mean number of aortic endothelial cells in the study sample group ( $p$-value 0.020). However, the LSD test did not find a significant difference between the dose groups, meaning that the three doses of cowpea extract (Vigna Unguiculata) described the same ability 
to prevent a decrease in the number of aortic endothelial cells. Meanwhile, the ovariectomized rats group, given $0.18 \mathrm{mg} / \mathrm{kg}$ BW/day of $17-\beta$ estradiol, showed a higher mean than the other treatment groups but not higher than the negative control.



Description: The mean number of aortic endothelial cells were checked on preparations histopathology with Hematoxylin \& Eosin (HE) staining and read with $400 x$ magnification on a ten field of view

Figure 2. Histogram of the Effect of Cowpea (Vigna unguiculata) Ethanol Extract on the Number of Aortic Endothelial Cells in Ovariectomized Rats



Description: Histopathological features of the aorta in the control group after staining with Hematoxylin \& Eosin (HE) endothelial cells appear purplish and adhere to the epithelium (arrows); (A) There are many endothelial cells attached to the epithelium (arrows) in the negative control group; (B) No endothelial cells were seen in the positive control group (HE, x400)

Figure 3. Histopathologic Features of the Aorta in the Control Group 


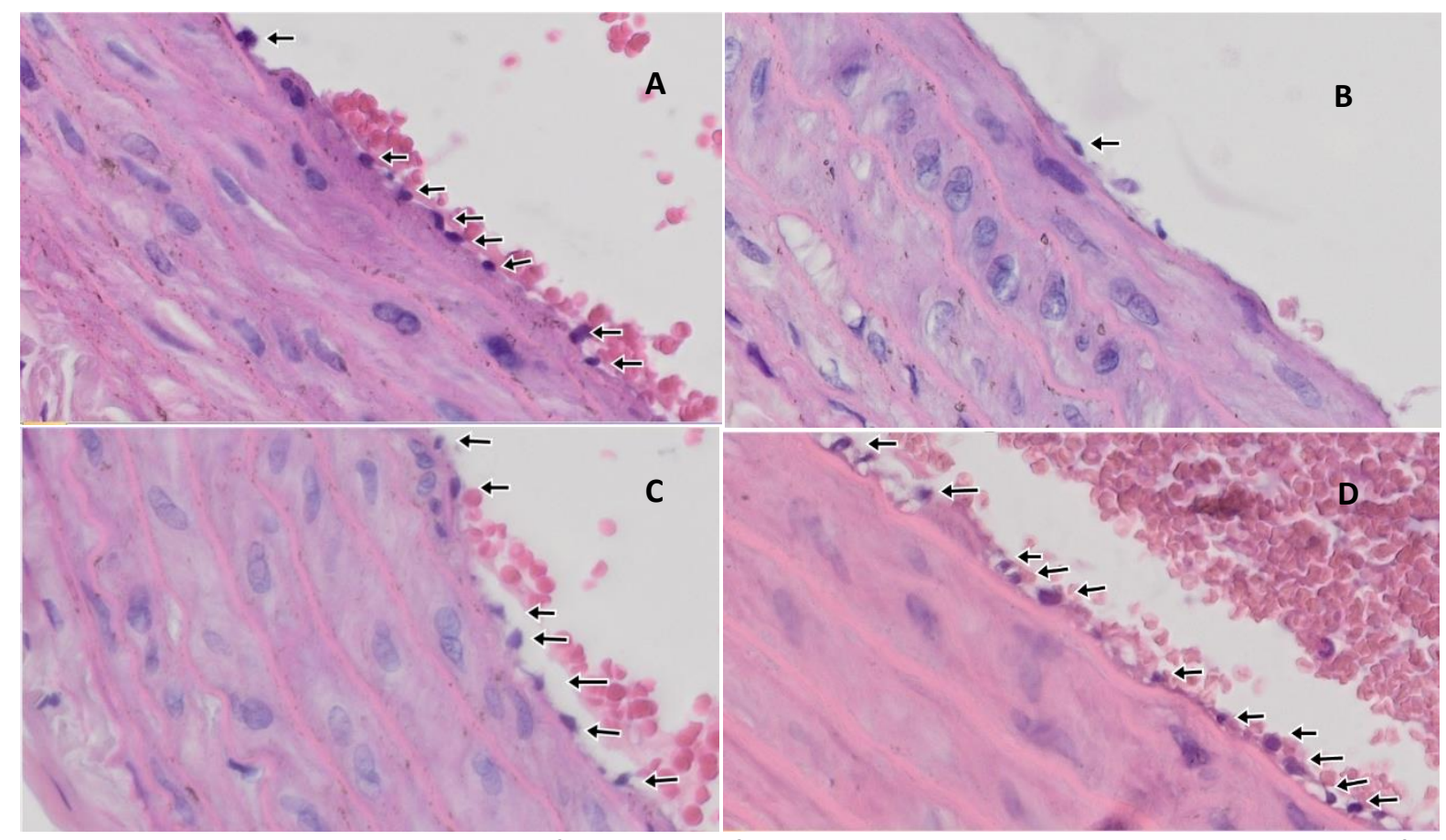

Description: Histopathological features of the aorta in the treatment group, after staining with Hematoxylin Eosin (HE) endothelial cells appear purplish in color and adhere to the epithelium. Each group saw differences in the number of endothelial cells indicated by arrows; (A) KP 1: Ovx $+17-\beta$ estradiol $0.18 \mathrm{mg} / \mathrm{kgBW} /$ day; (B) KP 2: Ovx + Vu 1.25 mg/kgBW/day; (C) KP 3: Ovx + Vu 2.5 mg/kgBW/day; (D) KP 4: Ovx + Vu $5 \mathrm{mg} / \mathrm{kgBW} /$ day $(\mathrm{HE}, \mathrm{x} 400)$

Figure 4. Histopathologic Features of the Aorta in the Treatment Group

\section{Brain MDA Level}

Figure 5 shows the mean value of brain MDA levels in each group. There was an increase in brain MDA levels in the positive control group compared to the negative control group. The mean value of brain MDA levels decreased with increasing the dose given. The process of testing the effect of Vigna unguiculata extract on brain MDA levels was carried out with One Way ANOVA, which proved there was a significant difference between the six groups of observed samples ( $p$-value 0.008). In the Least Significant Difference (LSD) test, it was found that the three doses of cowpea extract (Vigna Unguiculata) (1.25 mg/kg BW; $2.5 \mathrm{mg} / \mathrm{kg} \mathrm{BW}$; and $5 \mathrm{mg} / \mathrm{kg} \mathrm{BW}$ ) described the same ability to reduce brain MDA levels. The average administration of 17-estradiol was lower than Vigna unguiculata extract at a dose of $1.25 \mathrm{mg} / \mathrm{kg} \mathrm{BW}$ and $2.5 \mathrm{mg} / \mathrm{kg}$ BW. However, higher than the administration of Vigna unguiculata extract at a dose of $5 \mathrm{mg} / \mathrm{kg} \mathrm{BW}$. 


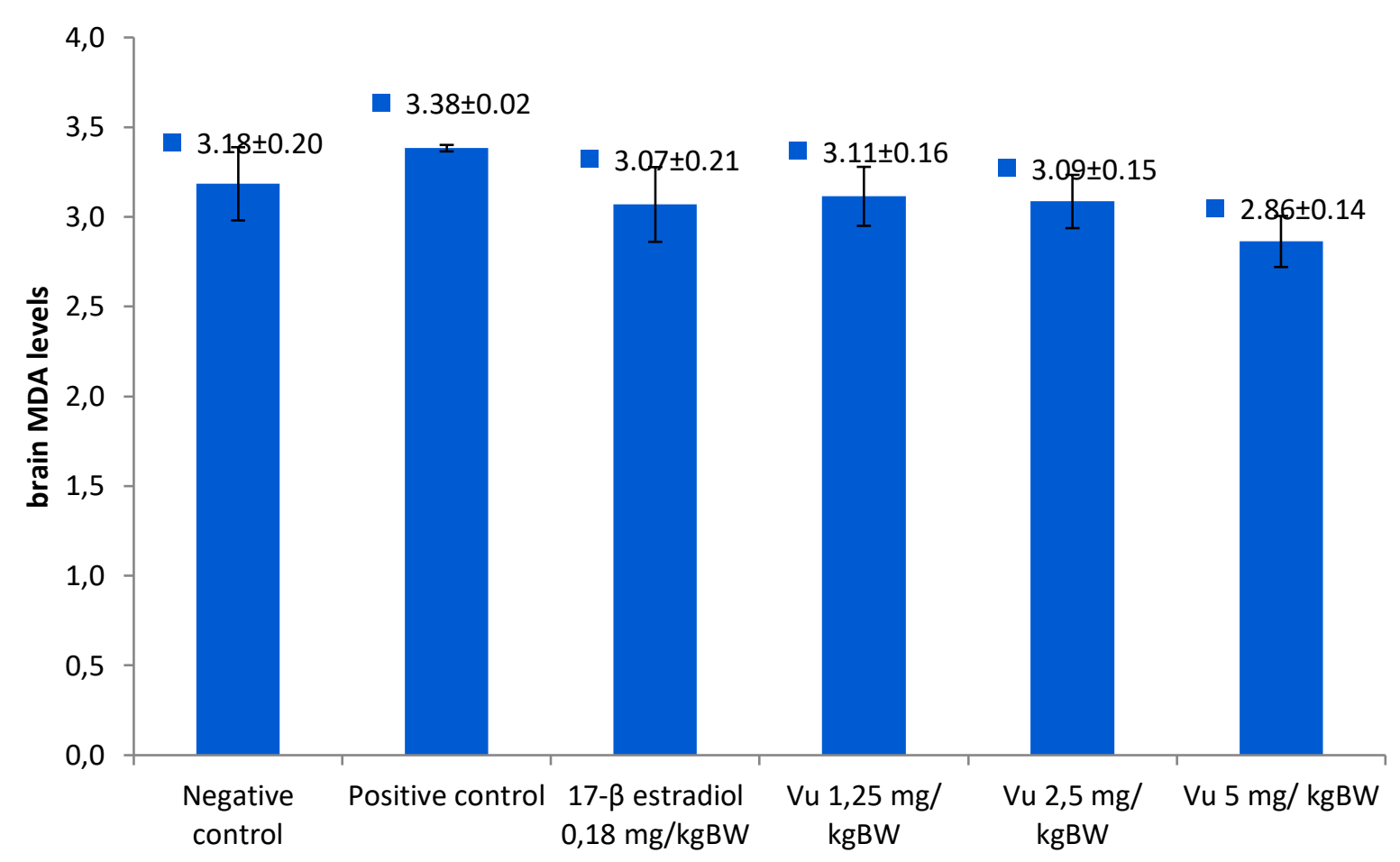

Description: The mean levels of MDA $(\mathrm{mg} / \mathrm{mL})$ brain were measured using ELISA

Figure 5. Histogram of the Effect of Cowpea (Vigna unguiculata) Ethanol Extract on Brain MDA Levels in Ovariectomized Rats

The gold standard in the preclinical field for evaluating the effects of female gonadal hormones using animal models is ovariectomy (Koebele \& Bimonte-Nelson, 2016). It is often used as a menopause model (Brinton, 2012). Ovariectomy is a surgical menopause model in which estrogen levels fall more rapidly than the decline in natural menopause. Menopause is an aging process that results in decreased function, decreased homeostasis, to cell death (apoptosis) due to a drastic reduction in the hormone estrogen. Apoptosis can occur in some cells in the heart, brain, and bones, causing impaired organ function (Kassi et al., 2015).

Serum and brain MDA levels in the positive control group showed a higher mean than the negative control group (figure 1, figure 5). This proves that ovariectomy further increases oxidative stress, causing MDA levels to increase. The results showed that the ethanolic extract of Vigna unguiculata could significantly reduce brain and serum MDA levels (figure 1, figure 5). In this study, brain and serum MDA levels became markers of oxidative conditions. The hypoestrogenic state causes a decrease in the body's defense against antioxidants so that the intracellular oxidation-reduction balance is damaged, and Reactive Oxygen Species (ROS) increases. This induces lipid and protein oxidation, impairs the integrity of Deoxyribonucleic acid (DNA), and ultimately causes tissue damage (Kassi et al., 2015).

Reactive Oxygen Species are highly reactive compounds that can attack their surroundings, including proteins, DNA, and lipids such as Polyunsaturated Fatty Acids (PUFA). Lipids are responsible for maintaining the integrity of cell membranes. However, extensive lipid peroxidation can change cell membrane lipids' formation, composition, structure, and dynamics in both neurons and osteoblasts (Gaschler \& Stockwell, 2017). The reaction that occurs between ROS and lipids is called lipid 
peroxidation. Lipid peroxidation occurs when free radicals such as $\mathrm{OH}$ attack Hydrogen from Fatty Acid (LH) and produce Radical Lipid (L•).

Furthermore, L• reacts with $\mathrm{O} 2$ molecules and forms Radical Peroxyl Lipid (LOO•). LOO• forms endoperoxides through a cyclization reaction, which ultimately forms MDA as the end product of the lipid peroxidation process. Lipid peroxidation is closely related to various diseases of the brain and the Central Nervous System (CNS). The phospholipids membrane in the CNS are organelles that are highly enriched with PUFA. This suggests that the CNS is susceptible to lipid peroxidation and induces neuronal cell death. Similar to the bone increased lipid peroxidation due to excessive bone resorption under hypoestrogenic conditions will trigger osteoblast cell apoptosis. If this happens continuously, it will cause a decrease in bone density (El Khoudary et al., 2015; Kassi et al., 2015).

Serum and brain MDA levels in the $17 \beta$-estradiol group were higher when compared to the $5 \mathrm{mg} / \mathrm{kg} \mathrm{BW}$ dose of Vigna unguiculata extract (figure 5). It means that the phytoestrogens in the extract of Vigna unguiculata can have a similar function to $17 \beta$-estradiol, an antioxidant that can prevent the increase in MDA levels (Devi et al., 2017).

The effect of the ethanolic extract of Vigna unguiculata on the number of aortic endothelial cells showed a significant difference between the study sample groups (figure 2). It should be emphasized that this study used ovariectomized rats aged 15 months, age at the onset of in rats (Sengupta, 2013). Aging and menopause are interrelated conditions and affect the estrogen response in blood vessels (Chakrabarti et al., 2014). Genistein contained in Vigna unguiculata is considered to have a good affinity with Estrogen Receptors (ER) because it has a chemical structure similar to 17ß-estradiol (Nikolić et al., 2017; Sureda et al., 2017). Estrogen provides a protective effect on vascular endothelium, and studies have shown that estrogen can exert a regenerating effect on the endothelium. Endothelial cell damage can be caused by an increase in ROS, which causes LDL oxidation to form a hydroxyl group which is characterized by an increase in MDA levels, according to the results of this study. Dysfunctional endothelium results in impaired vasodilation and increased oxidative stress (Darwin et al., 2018).

Endothelial cell loss or dysfunction can cause vascular damage so that both endogenous and extrinsic coagulation pathways are activated, and vascular stenosis or occlusion occurs (Meng et al., 2018). Endothelial damage and activation can lead to increased adhesion molecules and Endothelial Microvesicle (EMV) release, thereby triggering the recruitment of Endothelial Progenitor Cells (EPCs) for endothelial cell repair (Edwards et al., 2018). Endothelial regeneration involves endogenous endothelial cells and other (exogenous) cells (Evans et al., 2021). However, in general, endothelial regeneration is currently not clearly understood.

This study found that the positive control group had a lower mean number of endothelial cells than the negative control group (figure 2). Statistically, it was known that the three doses of Vigna unguiculata ethanol extract had the same ability to increase the number of endothelial cells. However, the extract had a positive trend in preventing a decrease in aortic endothelial cells in ovariectomized rats. It was proven that there was an increase in the number of aortic endothelial cells and extract dose.

The study also showed that ovariectomized rats given 17- $\beta$ estradiol at a dose of $0.18 \mathrm{mg} / \mathrm{kg} \mathrm{BW} /$ day showed a higher mean than the other treatment groups, but not higher than the negative control (figure 2). The administration of $17 \beta$-estradiol was judged to improve endothelial function with its anti-inflammatory properties and decrease ROS (Fontaine et al., 2020; Vanhoutte et al., 2017). 
In addition, genistein in Vigna unguiculata can activate Nrf2/ARE (Nuclear factor (erythroid-derived 2) as an antioxidant responsive element in cells to produce endogenous antioxidants. 7'- hydroxyl with estradiol as endogenous estrogen. This similarity of characteristics makes it easier for genistein to bind to estrogen hormonebinding proteins and estrogen receptors to directly inactivate ROS by activating the expression of endogenous antioxidant enzymes (Devi et al., 2017; Sureda et al., 2017).

There has been researching on the effect of genistein supplementation in reducing MDA (Braxas et al., 2019) and previous research on the effect of cowpea extract on MDA levels (Azizah et al., 2014). However, to see a more significant effect of genistein using experimental animals with more representative aging conditions, this study used cowpea variety KT4 (higher genistein content than other varieties) with 15-month-old rats as objects. The purpose of this study was to analyze the effect of cowpea extract on serum MDA levels, aortic endothelial cell counts, and brain MDA levels in the Rattus norvegicus ovariectomy model.

The limitations of this study are that the variables used are limited, and there are still many variables related to postmenopausal problems that have not been discussed in this study, such as stroke, diabetes, rheumatoid arthritis, and a few more. Therefore, further research is recommended to examine the effect of cowpea extract on some of these problems.

\section{CONCLUSION}

This study indicates that the ethanolic extract of cowpea (Vigna unguiculata) has the potential as an antioxidant to reduce serum MDA levels and prevent a decrease in the number of aortic endothelial cells and reduce brain MDA. As prevention, cowpea extract can be used as an antioxidant and consumed since premenopause to minimize problems that occur during postmenopause.

\section{CONFLICT OF INTEREST}

All authors state that there is no conflict or problem with any party in the writing of this journal publication.

\section{REFERENCES}

Azizah, I., Wahyuningrum, T., Keman, K., Santoso, S. \& Hidayati, D. Y. N. (2014). The effects of Vigna unguiculata on aortic endothelial cells, endothelial nitric oxide synthase expression, lipid profile, and atherosclerosis in ovariectomized rats. Journal of Experimental \& Integrative Medicine, 4(3).

Braxas, H., Rafraf, M., Karimi Hasanabad, S. \& Asghari Jafarabadi, M. (2019). Effectiveness of Genistein Supplementation on Metabolic Factors and Antioxidant Status in Postmenopausal Women With Type 2 Diabetes Mellitus. Canadian Journal of Diabetes, 43(7), 490-497. https://doi.org/10.1016/j.jcjd.2019.04.007

Brinton, R. D. (2012). Minireview: Translational Animal Models of Human Menopause: Challenges and Emerging Opportunities. 153(August), 3571-3578. https://doi.org/10.1210/en.2012-1340

Chakrabarti, S., Morton, J. S. \& Davidge, S. T. (2014). Mechanisms of estrogen effects on the endothelium: An overview. Canadian Journal of Cardiology, 30(7), 705712. https://doi.org/10.1016/j.cjca.2013.08.006

Darwin, E., Elfi, E. F. \& Dwitya, E. (2018). Endotel: Fungsi dan Disfungsi. Andalas University Press.

Devi, K. P., Shanmuganathan, B., Manayi, A., Nabavi, S. F. \& Nabavi, S. M. (2017). Molecular and Therapeutic Targets of Genistein in Alzheimer's Disease. 
Molecular Neurobiology, 54(9), 7028-7041. https://doi.org/10.1007/s12035-0160215-6

Edwards, N., Langford-Smith, A. W. W., Wilkinson, F. L. \& Alexander, M. Y. (2018). Endothelial progenitor cells: new targets for therapeutics for inflammatory conditions with high cardiovascular risk. Frontiers in Medicine, 5(JUL), 1-11. https://doi.org/10.3389/fmed.2018.00200

El Khoudary, S. R., Santoro, N., Chen, H. Y., Tepper, P. G., Brooks, M. M., Thurston, R. C., Janssen, I., Harlow, S. D., Barinas-Mitchell, E., Selzer, F., Derby, C. A., Jackson, E. A., McConnell, D. \& Matthews, K. A. (2015). Trajectories of estradiol and follicle-stimulating hormone over the menopause transition and early markers of atherosclerosis after menopause. European Journal of Preventive Cardiology, 23(7), 694-703. https://doi.org/10.1177/2047487315607044

Evans, C. E., Iruela-Arispe, M. L. \& Zhao, Y. Y. (2021). Mechanisms of Endothelial Regeneration and Vascular Repair and Their Application to Regenerative Medicine. American Journal of Pathology, 191(1), 52-65. https://doi.org/10.1016/j.ajpath.2020.10.001

Fontaine, C., Morfoisse, F., Tatin, F., Zamora, A., Zahreddine, R., Henrion, D., Arnal, J., Lenfant, F. \& Garmy-susini, B. (2020). The Impact of Estrogen Receptor in Arterial and Lymphatic Vascular Diseases.

Gaschler, M. M. \& Stockwell, B. R. (2017). Lipid peroxidation in cell death. Biochemical and Biophysical Research Communications, 482(3), 419-425. https://doi.org/10.1016/j.bbrc.2016.10.086

Hardiany, N. S., Sucitra, S. \& Paramita, R. (2020). Profile of malondialdehyde (MDA) and catalase specific activity in plasma of elderly woman. Health Science Journal of Indonesia, 10(2), 132-136. https://doi.org/10.22435/hsji.v12i2.2239

Huang, W. J., Zhang, X. \& Chen, W. W. (2016). Role of oxidative stress in Alzheimer's disease (review). Biomedical Reports, 4(5), 519-522. https://doi.org/10.3892/br.2016.630

Kassi, E., Spilioti, E., Nasiri-Ansari, N., Adamopoulos, C., Moutsatsou, P., Papapanagiotou, A., Siasos, G., Tousoulis, D. \& Papavassiliou, A. (2015). Vascular Inflammation and Atherosclerosis: The Role of Estrogen Receptors. Current Medicinal Chemistry, 22(22), 2651-2665. https://doi.org/10.2174/0929867322666150608093607

Klawitter, J., Hildreth, K. L., Christians, U., Kohrt, W. M. \& Moreau, K. L. (2017). A relative L-arginine deficiency contributes to endothelial dysfunction across the stages of the menopausal transition. Physiological Reports, 5(17), 1-13. https://doi.org/10.14814/phy2.13409

Koebele, S. V \& Bimonte-Nelson, H. A. (2016). Modeling menopause: The utility of rodents in translational behavioral endocrinology research. Maturitas, 87(1), 517. https://doi.org/doi:10.1016/j.maturitas.2016.01.015

Kusumaningrum, A. G., Prijadi, B. \& Aris, W. M. (2017). Efek ekstrak kacang tunggak (Vigna unguiculata) terhadap kadar Superoksida Dismutase ( SOD ) serum tikus galur wistar ( Rattus norvegicus ) yang dipapar dengan asap mesin berbahan bakar bensin. Majalah Kesehatan FKUB, 4(1), 1-8.

Mccarron, J. G., Lee, M. D. \& Wilson, C. (2017). The Endothelium Solves Problems That Endothelial Cells Do Not Know Exist. Trends in Pharmacological Sciences, 38(4), 322-338. https://doi.org/10.1016/j.tips.2017.01.008

Meng, L. B., Chen, K., Zhang, Y. M. \& Gong, T. (2018). Common Injuries and Repair Mechanisms in the Endothelial Lining. Chinese Medical Journal, 131(19), 23382345. https://doi.org/10.4103/0366-6999.241805 
Montoya-estrada, A., Guadalupe, K., Veruete-bedolla, D. B., Ruiz-herrera, J. D., Villarreal-barranca, A., Romo-yañez, J., Ortiz-luna, G. F., Arellano-eguiluz, A., Solis-paredes, M., Flores-pliego, A., Espejel-nuñez, A., Estrada-gutierrez, G. \& Reyes-muñoz, E. (2020). Parameters of Oxidative Stress in Reproductive and Postmenopausal Mexican Women. 1-11.

Muthusami, S., Ramachandran, I., Muthusamy, B., Vasudevan, G., Prabhu, V., Subramaniam, V., Jagadeesan, A. \& Narasimhan, S. (2005). Ovariectomy induces oxidative stress and impairs bone antioxidant system in adult rats. Clinica Chimica Acta, 360(1-2), 81-86. https://doi.org/10.1016/j.cccn.2005.04.014

Nikolić, I., Savić-Gajić, I., Tačić, A. \& Savić, I. (2017). Classification and biological activity of phytoestrogens: A review. Advanced Technologies, 6(2), 96-106. https://doi.org/10.5937/savteh1702096n

Peacock, K. \& Ketvertis, K. (2020). Menopause (In: StatPe). StatPearls Publishing;

Phaniendra, A., Jestadi, D. B. \& Periyasamy, L. (2015). Free Radicals: Properties, Sources, Targets, and Their Implication in Various Diseases. Indian Journal of Clinical Biochemistry, 30(1), 11-26. https://doi.org/10.1007/s12291-014-0446-0

Qin, D., Zhang, H., Zhang, H., Sun, T., Zhao, H. \& Lee, W. H. (2019). Anti-osteoporosis effects of osteoking via reducing reactive oxygen species. Journal of Ethnopharmacology, https://doi.org/10.1016/j.jep.2019.112045

Ross, M. D. (2018). Endothelial Regenerative Capacity and Aging: Influence of Diet, Exercise, and Obesity. Current Cardiology Reviews, 14(4), 233-244. https://doi.org/10.2174/1573403×14666180726112303

Schneider, H. P. G. \& Birkhäuser, M. (2017). Quality of life in climacteric women. Climacteric, 20(3), 187-194. https://doi.org/10.1080/13697137.2017.1279599

Sengupta, P. (2013). The laboratory rat: relating its age with humans. International Journal of Preventive Medicine, 4(6), 624.

Serviente, C., Troy, L. M., De Jonge, M., Shill, D. D., Jenkins, N. T. \& Witkowski, S. (2016). Endothelial and inflammatory responses to acute exercise in perimenopausal and late postmenopausal women. American Journal of Physiology-Regulatory Integrative and Comparative Physiology, 311(5), R841R850. https://doi.org/10.1152/ajpregu.00189.2016

Sureda, A., Sanches Silva, A., Sánchez-Machado, D. I., López-Cervantes, J., Daglia, M., Nabavi, S. F. \& Nabavi, S. M. (2017). Hypotensive effects of genistein: From chemistry to medicine. Chemico-Biological Interactions, 268, 37-46. https://doi.org/10.1016/j.cbi.2017.02.012

Usselman, C. W., Stachenfeld, N. S. \& Bender, J. R. (2016). The molecular actions of estrogen in the regulation of vascular health. Experimental Physiology, 101(3), 356-361. https://doi.org/10.1113/EP085148

Vanhoutte, P. M., Shimokawa, H., Feletou, M. \& Tang, E. H. C. (2017). Endothelial dysfunction and vascular disease - a 30th-anniversary update. Acta Physiologica, 219(1), 22-96. https://doi.org/10.1111/apha.12646

Ventura-Clapier, R., Dworatzek, E., Seeland, U., Kararigas, G., Arnal, J. F., Brunelleschi, S., Carpenter, T. C., Erdmann, J., Franconi, F., Giannetta, E., Glezerman, M., Hofmann, S. M., Junien, C., Katai, M., Kublickiene, K., König, I. R., Majdic, G., Malorni, W., Mieth, C., ... Regitz-Zagrosek, V. (2017). Sex in basic research: Concepts in the cardiovascular field. Cardiovascular Research, 113(7), 711-724. https://doi.org/10.1093/cvr/cvx066

Wang, Jie-mei, Chen, A. F. \& Zhang, K. (2016). Isolation and Primary Culture of Mouse Aortic Endothelial Cells. December, 1-7. https://doi.org/10.3791/52965 
Wang, Jinsong, Peng, X., Lassance-Soares, R. M., Najafi, A. H., Alderman, L. O., Sood, S., Xue, Z., Chan, R., Faber, J. E., Epstein, S. E. \& Burnett, M. S. (2011). Aging-induced collateral dysfunction: Impaired responsiveness of collaterals and susceptibility to apoptosis via dysfunctional eNOS signaling. Journal of Cardiovascular Translational Research, 4(6), 779-789. https://doi.org/10.1007/s12265-011-9280-4 